\title{
Electrical System Design and Installation of New Building, Aisyiyah University, Yogyakarta
}

\author{
Slamet Suripto $^{* 1}$, Agus Jamal ${ }^{1}$, Kunnu Purwanto ${ }^{1}$, Wahyu Nugroho Wicaksono ${ }^{1}$, Yessi Jusman ${ }^{2}$ \\ ${ }^{1}$ Department of Electrical Engineering, Faculty of Engineering, Universitas Muhammadiyah \\ Yogyakarta) \\ Bantul 55183 Daerah Istimewa Yogyakarta, Indonesia \\ ${ }^{2}$ Department of Informatics Engineering, Faculty of Engineering, Universitas Abdurrab \\ Pekanbaru, Riau, Indonesia \\ *Corresponding author, e-mail: agus_jamal@umy.ac.id
}

\begin{abstract}
Aisyiyah University New Yogyakarta Building is one of the commercial buildings that moves the field of education in Yogyakarta. The New Building of Aisyiyah University Yogyakarta consists of 10 floors, including the basement floor, main floor and roof floor. Electric loads installed at the New Building of Aisyiyah University Yogyakarta include lighting loads (lights) and power loads (sockets) and the power loads of electric motors (air conditioners, elevators and others), which of course requires a large enough electricity supply. Electricity installed in the New Building of Aisyiyah University in Yogyakarta is $1010.9 \mathrm{kVA}$. The power supplied is $800 \mathrm{kVA}$ from State Electricity Company and the total power capacity of the transformer is $1000 \mathrm{kVA}$ and a generator set with a capacity of $1000 \mathrm{kVA}$. Where the backup power supply system is fully supplied by the generator set.
\end{abstract}

Keywords: Electrical Installation, Artificial Lighting, Short-circuit Current, Power Distribution, Drop Voltage

\section{Introduction}

As one of the facilities and infrastructure to support the learning process, a university needs to pay attention to the quality of service facilities and infrastructure in order to provide a sense of comfort and peace for students and their community. This comfort and peace will not be obtained without the presence of good supporting facilities and infrastructure from universities. In the construction of a building in general and universities in particular, it is inseparable from the need for electrical energy. In a building, electrical energy is needed, ranging from lighting systems to lightning protection systems. Therefore, it is necessary to design a system and electrical installation at universities.

In designing an electrical installation a tertiary institution must comply with the provisions of the General Electrical Installation Requirements and the
Indonesian National Standard so that electrical energy can be used safely, reliably and effectively [1]. This design is made with the intent and purpose to understand the general rules of electrical installation and can learn and know how to design, install, check, test, maintain and supervise an electrical installation. A high-performance electrical installation design needs to be designed in detail so as not to over-design.

\section{Methods}

Flowchart for the research is presented in Fig. 1.

1. Designing system design

Starting from the design of artificial lighting systems, installation of contact boxes, electrical distribution system design, lightning protection systems and grounding systems using the AutoCAD application. 
2. Analysis, calculation, and discussion of electrical installation system design

All systems that have been made will be analyzed and calculated and considered whether all systems are in accordance with installation standards and the system will work properly.

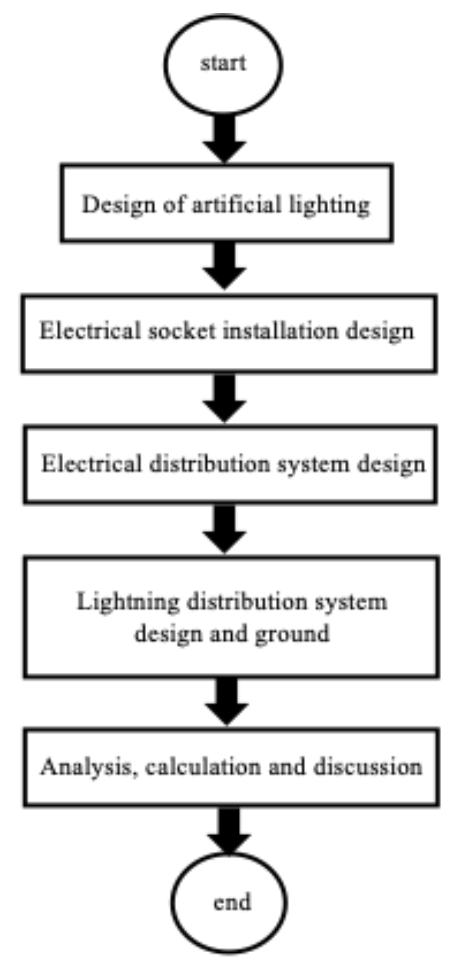

Fig. 1. Flowchart

\section{Results}

\section{III.1. Determination of the Number of Lamp Armature Points}

The following is a calculation for one of the rooms on the 4th floor:

1. Main room

- Type of lamp to be installed $=14$ Watt LED Lamps

- Luminous lamp flux $(\Phi)=1400$ lumens

- Lux room according to SNI (E) $=350 \mathrm{Lux}$

- $\operatorname{Run}$ area $(\mathrm{A})=290 \mathrm{~m}^{2}$

- Light loss factor (LLF) $=0.8$

- Utility factor $(\mathrm{CU})=100 \%$ (estimated)

$$
\begin{gathered}
N=\frac{E \times A}{\emptyset \times L L F \times C U \times n} \\
\mathrm{~N}=\frac{350 \times 290}{1400 \times 0,8 \times 100 \% \times 1}=90,625
\end{gathered}
$$

So, the minimum number of light points needed is as many as 91 points.

As for the calculation of another room on the same floor using a light loss factor (LLF) of 0.8 and a utility factor (CU) of $100 \%$ are presented in Table I [2].

TABLE I

\begin{tabular}{|c|c|c|c|c|}
\hline No. & Room Names & Large & Lux & $\begin{array}{c}\text { Amount } \\
\text { ideal }\end{array}$ \\
\hline 1 & Main room & 290 & 350 & 91 \\
\hline 2 & Stair Area 2 & 24 & 100 & 3 \\
\hline 3 & Stair Area 1 & 21 & 100 & 3 \\
\hline 4 & Lobby Side Services & 23.5 & 100 & 3 \\
\hline 5 & Corridor & 160 & 100 & 20 \\
\hline 6 & Men's Toilet & 11 & 250 & 4 \\
\hline 7 & Women's Toilet & 13 & 250 & 4 \\
\hline 8 & Janitor & 3.5 & 100 & 1 \\
\hline 9 & Special Toilet & 4 & 250 & 1 \\
\hline 10 & $\begin{array}{l}\text { Male Ablution } \\
\text { Room }\end{array}$ & 1.3 & 250 & 1 \\
\hline 11 & $\begin{array}{l}\text { Women's Ablution } \\
\text { Room }\end{array}$ & 1.3 & 250 & 1 \\
\hline 12 & Nursing Room & 2 & 250 & 1 \\
\hline 13 & Panel Room & 3 & 250 & 1 \\
\hline 14 & Room 01 & 102 & 250 & 23 \\
\hline 15 & Room 02 & 98 & 250 & 22 \\
\hline 16 & Room 03 & 98 & 250 & 22 \\
\hline 17 & Room 04 & 101 & 250 & 23 \\
\hline 18 & Room 05 & 59 & 250 & 13 \\
\hline 19 & Room 06 & 59 & 250 & 13 \\
\hline
\end{tabular}

CALCUlation OF Number OF LAMP POINTS $4^{\mathrm{TH}}$ FLOOR

\section{III.2. Panel Load Schedule}

Lighting panel and 4th floor contact box. All MCB group ratings on the 4th floor LP \& PP panel are 16A.

1. MCB group 1 (PL-4/01)

- Installed Load:

- LED Lamps 14W x 93 pieces = 1302 Watt

- LED Lamps 14W + Battery x 7 pieces $=98$ Watts

- Total installed load power $(\mathrm{P})=1400 \mathrm{Watt}$

- Voltage (V) / Phase / Frequency $(F)=220 \mathrm{~V}$ $/ 1 / 50 \mathrm{~Hz}$ (State Electricity Company)

- Assumption cos $\Phi=0.85$

- Installed load current (I):

$$
I=\frac{P}{V_{L N} * \operatorname{COS} \emptyset}=\frac{1400}{220 * 0,85}=7.49 \mathrm{~A}
$$

The calculation for the next MCB group with the assumption strength of each outlet is $100 \mathrm{~W}$ and uses 
equation 2, as presented in Table II.

TABLE II

Calculation of the 4Th Floor Panel Load Schedule

\begin{tabular}{|c|c|c|c|c|}
\hline No. & $\begin{array}{l}\text { Group } \\
\text { Panel }\end{array}$ & $\begin{array}{l}\text { Load Type } \\
\text { Installed }\end{array}$ & $\begin{array}{c}\text { Load } \\
(\mathrm{W})\end{array}$ & $\begin{array}{c}\text { Current } \\
\text { Load }\end{array}$ \\
\hline 1 & PL-4/01 & $\begin{array}{l}\text { Led lamps 14W } \\
\text { + Battery }\end{array}$ & $\begin{array}{c}1302 \\
98\end{array}$ & 7.49 \\
\hline 2 & PL-4/02 & $\begin{array}{l}\text { Led lamps 10W } \\
+ \text { Battery }\end{array}$ & $\begin{array}{c}360 \\
60\end{array}$ & 2.25 \\
\hline 3 & PL-4/03 & $\begin{array}{c}\text { Led lamps 10W } \\
\text { + Battery } \\
\text { Led T8 9W } \\
\text { + Battery }\end{array}$ & $\begin{array}{c}120 \\
20 \\
18 \\
9\end{array}$ & 0.89 \\
\hline 4 & PL-4/04 & $\begin{array}{l}\text { Led lamps 14W } \\
+ \text { Battery }\end{array}$ & $\begin{array}{c}406 \\
14\end{array}$ & 2.25 \\
\hline 5 & PL-4/05 & $\begin{array}{l}\text { Led lamps } 14 \mathrm{~W} \\
+ \text { Battery }\end{array}$ & $\begin{array}{c}406 \\
14\end{array}$ & 2.25 \\
\hline 6 & PL-4/06 & $\begin{array}{l}\text { Led lamps 14W } \\
+ \text { Battery }\end{array}$ & $\begin{array}{c}406 \\
14\end{array}$ & 2.25 \\
\hline 7 & PL-4/07 & $\begin{array}{l}\text { Led lamps } 14 \mathrm{~W} \\
+ \text { Battery }\end{array}$ & $\begin{array}{c}406 \\
14\end{array}$ & 2.25 \\
\hline 8 & PL-4/08 & $\begin{array}{l}\text { Led lamps 14W } \\
+ \text { Battery }\end{array}$ & $\begin{array}{c}224 \\
14\end{array}$ & 1.27 \\
\hline 9 & PL-4/09 & $\begin{array}{l}\text { Led lamps 14W } \\
\text { + Battery }\end{array}$ & $\begin{array}{c}224 \\
14\end{array}$ & 1.27 \\
\hline 10 & ES-4/01 & $\begin{array}{l}\text { Wall ES } 40 \mathrm{~cm} \\
\text { Wall ES } 150 \mathrm{~cm} \\
\text { Wall ES } 40 \mathrm{~cm}\end{array}$ & $\begin{array}{l}400 \\
100 \\
400\end{array}$ & 2.67 \\
\hline 11 & ES-4/02 & $\begin{array}{c}\text { Floor ES } \\
\text { Projector ES } \\
\text { Wall ES } 40 \mathrm{~cm}\end{array}$ & $\begin{array}{l}125 \\
250 \\
400\end{array}$ & 4.14 \\
\hline 12 & ES-4/03 & $\begin{array}{c}\text { Floor ES } \\
\text { Projector ES } \\
\text { Wall ES } 40 \mathrm{~cm}\end{array}$ & $\begin{array}{l}125 \\
250 \\
400\end{array}$ & 4.14 \\
\hline 13 & ES-4/04 & $\begin{array}{c}\text { Floor ES } \\
\text { Projector ES } \\
\text { Wall ES } 40 \mathrm{~cm}\end{array}$ & $\begin{array}{l}125 \\
250 \\
400\end{array}$ & 4.14 \\
\hline 14 & ES-4/05 & $\begin{array}{c}\text { Floor ES } \\
\text { Projector ES } \\
\text { Wall ES } 40 \mathrm{~cm}\end{array}$ & $\begin{array}{l}125 \\
250 \\
200\end{array}$ & 4.14 \\
\hline 15 & ES-4/06 & $\begin{array}{l}\text { Wall ES } 150 \mathrm{~cm} \\
\text { Floor ES }\end{array}$ & $\begin{array}{l}200 \\
125\end{array}$ & 4.14 \\
\hline $\begin{array}{l}16 \\
17\end{array}$ & $\begin{array}{l}\text { ES-4/07 } \\
\text { ES-4/08 }\end{array}$ & $\begin{array}{l}\text { Wall ES } 40 \mathrm{~cm} \\
\text { Wall ES } 40 \mathrm{~cm}\end{array}$ & $\begin{array}{l}400 \\
400\end{array}$ & $\begin{array}{l}2.14 \\
2.14\end{array}$ \\
\hline 18 & ES-4/09 & $\begin{array}{c}\text { Floor ES } \\
\text { Projector ES }\end{array}$ & $\begin{array}{l}125 \\
500\end{array}$ & 3.34 \\
\hline 19 & ES-4/10 & $\begin{array}{l}\text { Wall ES } 40 \mathrm{~cm} \\
\text { Wall ES } 40 \mathrm{~cm}\end{array}$ & $\begin{array}{l}600 \\
200\end{array}$ & 3.21 \\
\hline 20 & ES-4/11 & $\begin{array}{c}\text { Wall ES } 150 \mathrm{~cm} \\
\text { Floor ES }\end{array}$ & $\begin{array}{l}200 \\
125\end{array}$ & 4.14 \\
\hline
\end{tabular}

\section{Main room}

Loads from all groups are divided into phases $\mathrm{R}$, $\mathrm{S}$ and $\mathrm{T}$, so that the load current installed in the three phases is balanced or close. The distribution of the full load can be seen in the appendix chapter, each value of installed load current per phase of the sum of all groups is as follows.

- Phase R (IR) = 19.0 A

- Phase $\mathrm{S}(\mathrm{IS})=18.8 \mathrm{~A}$

- Phase $\mathrm{T}(\mathrm{IT})=19.3 \mathrm{~A}$
3. Main Circuit Breaker (CB)

Main $\mathrm{CB}$ is the main circuit breaker for this panel.

- Built-in load current (I) = 19.3 A in phase R (taken only from the phase that has the highest value)

- Minimum current carrying capacity (CRC) cable installation (I CRC):

- $\mathrm{I}$ KHA $=\mathrm{I} * 125 \%=19.3 * 125 \%=24.2 \mathrm{~A}$

- The type of CB selected is a fixed-phase 3phase MCCB (molded case circuit breaker), because it has a high resistance to heat.

- The MCCB rating must be higher than the group $\mathrm{MCB}$ rating (16A) and the installation cable CRC (I KHA = 24.125 A).

- For future load growth reserves, the chosen rating is $30 \mathrm{~A}$, according to the brochure available on the market.

\section{Feeder cable}

Feeder cable, pulled from SDP Gedung to PL \& PP 4th Floor panel.

- The grounding cable used is bare copper cable, which is the BCC cable.

- Minimum cable crosssectional area (A GROUND):

- $A$ GROUND $=A$ FEEDER $* 50 \%=6 \mathrm{~mm}^{2} \mathrm{x}$ $50 \%=3 \mathrm{~mm}^{2}$

- In accordance with the available brochure, the selected grounding cable is BCC $6 \mathrm{~mm}^{2}$

\section{III.3. LVMDP Load Schedule}

1. Distribution of Loads to Phase R, S, and T

After multiplying by the simultaneity factor, the estimated load which was previously $840.0 \mathrm{kVA}$ (installed electrical load) becomes $663.8 \mathrm{kVA}$ (normal maximum load). Then, the electric current can be calculated, as follows.

- Phase R (IR) = 1011.2 A

- Phase $S$ (IS) $=1018.6 \mathrm{~A}$

- Phase T $($ IT $)=1011.9 \mathrm{~A}$

\section{Main Circuit Breaker (CB)}

Main $\mathrm{CB}$ is the main circuit breaker for this panel.

- Built-in load current (I) = 1018.6 A in phase $S$ (taken only from the phase that has the highest value).

- The type of CB selected is a 3 phase MCCB (miniature circuit breaker) fix type, because it has a high resistance to heat.

- For future load growth reserves, the chosen rating is $1250 \mathrm{~A}$, according to the brochure 
available on the market.

\section{Feeder cable}

Feeder cable, pulled from transformer to LVMDP

- Minimum current carrying capacity (CRC) cable installation (I CRC ):

- $\mathrm{I}$ KHA $=\mathrm{I} * 125 \%=1018.6 * 125 \%=1273.25$ A

- The feeder cable used is copper cable with double PVC insulation, i.e. NYY cable.

- The cable used consists of four cores; that is, for phase $R$, phase $S$, phase $T$ and neutral.

- The cable CRC must not be less than 1250A (main MCCB rating) and should consider Voltage drop on the cable.

- In accordance with the available brochure, the chosen cable is NYY $4 \times\left(4 \times 1 \times 300 \mathrm{~mm}^{2}\right)$ with a CRC of 2208A.

\section{Grounding cable}

Grounding cable, pulled from the Grounding Well to LVMDP.

- The grounding cable used is bare copper cable, which is the BCC cable.

- Minimum cable crosssectional area (A GROUND ):

- $A$ GROUND $=$ A FEEDER $* 50 \%=(4 \times 300)$ $\mathrm{mm}^{2} \times 50 \%=2 \times 300 \mathrm{~mm}^{2}$

- In accordance with the available brochure, the selected grounding cable is 2 x BCC 300 $\mathrm{mm}^{2}$

\section{III.4. Power Factor Improvement}

After getting the total amount of apparent power and active power, then the reactive power calculation can be done in order to determine the capacity of the capacitor bank that is needed as an effort to improve the power in the building [3]. The formula to be used in calculating reactive power is presented in equation 3 .

$$
Q=\sqrt{S^{2}-P^{2}}
$$

Information:

$\mathrm{Q}=$ reactive power $(\mathrm{VAR})$

$\mathrm{S}=$ Pseudo power $(\mathrm{VA})$

$\mathrm{P}=$ Active power $(\mathrm{W})$

1. Determine the total reactive power (VAR)

Determine the amount of reactive power obtained from apparent power and active power that has been multiplied by the togetherness factor (estimation). The apparent power $=663.9 \mathrm{kVA}$ and active power $=546.7 \mathrm{~kW}$ so that the following calculation is presented in equation 4 .

$$
\begin{gathered}
Q=\sqrt{S^{2}-P^{2}} \\
Q=\sqrt{663,9^{2}-546,7^{2}} \\
\mathrm{Q}=376,54 \mathrm{Kvar}
\end{gathered}
$$

2. Determine the value of $\operatorname{Cos} \Phi$ (phi) before power repair

The value of $\operatorname{Cos} \Phi$ (phi) before the power factor improvement is obtained by calculating as presented in equation 5 .

$$
\begin{gathered}
\operatorname{Cos} \Phi=\frac{546,7}{663,9} \\
\operatorname{Cos} \Phi=0.82
\end{gathered}
$$

From equation 5, the initial $\operatorname{Cos} \Phi$ (phi) found on the Aisyiyah University Yogyakarta campus is 0.82 while $\operatorname{Cos} \Phi$ required for the building is 0.92 . The calculation of the capacitor capacity of the bank to be installed is presented in equation 6 .

$$
\begin{gathered}
S 1=\frac{P}{0,92} \\
S 1=\frac{546,7}{0,92} \\
S 1=594,2 \mathrm{kVA}
\end{gathered}
$$

So the reactive power calculation if $\operatorname{Cos} \Phi$ is 0.92 , as presented in equation 7 .

$$
\begin{gathered}
Q 1=\sqrt{S 1^{2}-P^{2}} \\
Q 1=\sqrt{594,2^{2}-546,7^{2}} \\
\mathrm{Q} 1=232,89 \mathrm{kVAR}
\end{gathered}
$$

From the calculation of Cost $\Phi$ of 0.92 , it can be determined the amount of bank capacitors to be used, as presented in equation 8 .

$$
\begin{aligned}
& \mathrm{C}=\mathrm{Q}-\mathrm{Q} 1 \\
& \mathrm{C}=376,54-232,89 \\
& \mathrm{C}=143,7 \mathrm{kVAR}
\end{aligned}
$$

Then the amount of bank capacitors to be used on the campus of Yogyakarta Aisyiyah University is $143.7 \mathrm{kVAR}$ with a combination of $12 \times 25 \mathrm{kVAR}$. $12 \times 25 \mathrm{kVAR}$ combination is chosen, because the 
rest is used as a backup if one day there is damage or overreactive power.

\section{III.5. Genset and Transformer Capacity}

The main principle in determining the capacity of the generator and transformer is that the normal normal load must not exceed $75 \%$ of the capacity of the transformer and generator. The calculation that will be used to determine the capacity of the generator set and transformer is as follows:

1. The maximum normal load of buildings

The maximum normal load of buildings after improvement of the power factor is $594.2 \mathrm{kVA}$

2. Generator Capacity

Generator capacity is presented in equation 9 .

$$
\frac{594,2}{75 \%}=792,27 k V A
$$

In accordance with the brochure available and circulating in the market, the capacity of the generator used is $1000 \mathrm{kVA}$

\section{Transformer Capacity}

Transformer capacity is presented in equation 10 .

$$
\frac{594,2}{75 \%}=792,27 k V A
$$

In accordance with the brochure available and circulating in the market, the capacity of the transformer used is as much as $1000 \mathrm{kVA}$.

\section{State Electricity Company Power}

To determine the amount of subscription power that will be connected from State Electricity Company must refer to the estimated maximum normal load and from the State Electricity Company subscription power brochure. From the calculation results, the maximum normal load of Yogyakarta Aisyiyah University is $594.2 \mathrm{kVA}$, so that according to the power available at PLN's bureau, the power to be connected is $800 \mathrm{kVA}$

\section{III.6. Drop Voltage}

Following is an example of calculation of voltage drop from a Transformer to LVMDP Panel:

- Cable Type: NYY 4x (4x1x300 mm²)

- $\mathrm{R}=0.075 \Omega / \mathrm{kM}$

- $\mathrm{L}=0.000305 \mathrm{H} / \mathrm{kM}$
- $I=1488.7$ A

- $\mathrm{X} \mathrm{L}=0.09577 \Omega / \mathrm{kM}$

- $\operatorname{Cos} \Phi=0.78$ (Assumption)

- $\operatorname{Sin} \Phi=0.62$

- Drop Voltage is presented in equation 11.

$$
\begin{gathered}
\Delta V=\frac{\sqrt{3} x I x l x(R \cos \Phi+\mathrm{X} \sin \Phi)}{n} \\
\Delta \mathrm{V}=1.519670 \mathrm{~V} \\
\Delta V=\frac{\Delta V}{V} x 100 \% \\
\Delta V=\frac{1.51555}{380} \times 100 \% \\
\% \Delta \mathrm{V}=0.003999131 \%
\end{gathered}
$$

For each floor height is assumed to be 4 so that the length of the cable from one floor to another is added to 5 meters. The calculations for impendance and voltage drop for other panels are presented in Table III.

TABLE III

Calculation of Drop Voltage

\begin{tabular}{llcc}
\hline \hline No & \multicolumn{1}{c}{ Panel Name } & $\Delta \mathrm{V}(\mathrm{V})$ & $\Delta \mathrm{V}(\%)$ \\
\hline \hline & Outgoing LVMDP & & \\
\hline 1 & SDP Building & 2.511 & 0.006607695 \\
2 & SDP Pump & 0.148868 & 0.000391759 \\
3 & PK STP & 0.168856 & 0.000444357 \\
4 & PP Power House & 0.098499 & 0.000259208 \\
\hline & SDP Building & & \\
\hline 1 & SDP Lift & 0.665882 & 0.001752320 \\
2 & PC Pressurise Fan & 0.073431 & 0.000193239 \\
3 & PP Electronic & 0.058418 & 0.000153730 \\
4 & LP \& PP SB Floor & 0.328458 & 0.000864364 \\
5 & LP \& PP 1st Floor & 0.170239 & 0.000447998 \\
6 & PP AC 1st Floor & 0.319234 & 0.000840091 \\
7 & LP \& PP 2nd Floor & 0.232693 & 0.000612350 \\
8 & PP AC 2nd Floor & 0.400941 & 0.001055107 \\
9 & LP \& PP 3rd Floor & 0.265828 & 0.000699547 \\
10 & PP AC 3rd Floor & 0.347713 & 0.000915035 \\
11 & PP Server & 0.410922 & 0.001081375 \\
12 & LP \& PP 4th Floor & 0.412749 & 0.001086181 \\
13 & PP AC 4th Floor & 0.565592 & 0.001488401 \\
14 & LP \& PP 5th Floor & 0.503282 & 0.001324427 \\
15 & PP AC 5th Floor & 0.648195 & 0.001705776 \\
16 & LP \& PP 6th Floor & 0.565459 & 0.001488049 \\
17 & PP AC 6th Floor & 0.768230 & 0.002021658 \\
18 & LP \& PP 7th Floor & 0.925391 & 0.002435239 \\
19 & PP AC 7th Floor & 0.662977 & 0.001744675 \\
20 & LP \& PP 8th Floor & 1.036764 & 0.002728326 \\
21 & PP AC 8th Floor & 1.200454 & 0.003159090 \\
22 & SDP Roof & 0.828414 & 0.002180036 \\
\hline \hline & & &
\end{tabular}

\section{III.7. Short Circuit Current}

Calculation of short-circuit current in the transformer [4]. The following are the specifications listed on the transformer: 
- Transformer apparent power $(S r T)=1000$ $\mathrm{kVA}$

- Transformer voltage $(U r T)=20 \mathrm{kV} / 0.4 \mathrm{kV}$

- Number of phases $=3$

- Short circuit voltage $(U k r)=5 \%$.

- Total transformer loss $($ PkrT $)=13 \mathrm{~kW}$

To get a large short circuit current in a transformer, first look at the total impedance value in the transformer, which is presented in equation 12.

$$
\begin{gathered}
Z_{T}=\frac{U_{k r}}{100 \%} \times \frac{U_{r T L V}^{2}}{S_{r T}}=\frac{5 \%}{100 \%} \times \frac{0,4^{2}}{1000} \\
\mathrm{Z}_{\mathrm{THV}}=8 \mathrm{~m} \Omega \\
R_{T}=P_{K r T} \times \frac{U_{r T}^{2}}{S_{r T}^{2}}=13 \times \frac{0,4^{2}}{1000^{2}} \\
\mathrm{R}_{\mathrm{T}}=2,08 \mathrm{~m} \Omega \\
U_{R r}=100 \% x \frac{P_{k r T}}{S_{r T}}=100 \% \times \frac{13}{1000} \\
U_{R r}=1,3 \% \\
U_{X r}=\sqrt{U_{K r}{ }^{2}-U_{R r}^{2}}=\sqrt{5^{2}-1.3^{2}} \\
U_{X r}=4,828 \% \\
X_{T}=\sqrt{Z_{T}^{2}-R_{T}^{2}}=\sqrt{8^{2}-2,08^{2}} \\
\mathrm{X}_{\mathrm{T}}=7,725 \mathrm{~m} \Omega \\
C_{\max }=0,95 \frac{1,1}{1+0,6 X_{T}}=0,95 \frac{1+0,6 * 7,725}{1+0} \\
\mathrm{~K}_{\mathrm{T}}=1,015580404
\end{gathered}
$$

So the results of the calculation of the 3 phase short circuit sismetric short circuit on the transformer are presented in equation 13.

$$
\begin{gathered}
Z_{T}=\sqrt{{R_{T}{ }^{2}+X_{T}^{2}}^{2}=\sqrt{2,08^{2}+7,725^{2}}} \\
\mathrm{Z}_{\mathrm{T}}=8 \mathrm{~m} \Omega \\
Z_{T K}=Z_{T} * K_{T}=8 * 1.015580404 \\
\mathrm{Z}_{\mathrm{TK}}=8,125 \mathrm{~m} \Omega
\end{gathered}
$$

So that the 3-phase symmetry short circuit current can be calculated in the transformer, as presented in equation 14.

$$
\begin{gathered}
I^{n} K=\frac{C * U_{n}}{\sqrt{3} * Z_{T K}}=\frac{1.1 * 400}{\sqrt{3} * 8,125} \\
I^{n} K=31,26711058 \mathrm{kA}
\end{gathered}
$$

Based on equation 14, the initial short-circuit current is $31.27 \mathrm{kA}$

\section{III.8. Building Protection Level}

Based on the General Rules of Lightning Arrangement Installation in Indonesia, the magnitude of the need for installing lightning arrest system against lightning strikes in a building is determined by adding up the indices that represent the situation in the location of the structure is located. Then for the building indexes are obtained as follows:

1. Index A, Usage and Content Index A

Use and Content of Yogyakarta Aisyiyah University Building Planning is an educational building with an Index Value $=3$.

\section{Index B, Building Construction}

This building includes buildings with reinforced concrete construction or iron frames with non-metal roofs. Index Value $=2$.

\section{Index C, Building Height}

This building has a height of up to 35 meters. Index Value $=5$

\section{Index D, Building Situation}

This building is on a flat ground at all height with an index value $=0$.

\section{Index E, lightning effect}

Based on the number of thunder days per year to reach 182.5 days per year, then the Index Value $\mathrm{E}=$ 8. Total number the index value above is in accordance with the equation $R=A+B+C+D+$ $E$ obtained the value of $\mathrm{R}=18$ Then the estimated danger of lightning strikes is very large and securing lightning strikes against buildings is very necessary [5].

\section{III.9. Election of Lightning Rods}

The high lightning rod installed in a building is very influential on the radius of protection, the higher the lightning rod installation, the wider the 
protected area. Based on the Indonesian National Standard number 03-7015-2004 concerning lightning protection systems in buildings, in the New Building, Yogyakarta Aisyiyah University, Flash Vectron lightning rods based on ESE (Early Streamer Emission) will be installed [6].

\section{Conclusion}

Based on the results of the design that has been done in this study, the results obtained are:

1. The total active power in planning the construction of the new building of Aisyiyah University in Yogyakarta is $680.7 \mathrm{~kW}$ and the total apparent power is $840.0 \mathrm{kVA}$.

2. In an effort to increase cos phi from 0.82 to 0.92 , a capacitor bank with a capacity of $143.7 \mathrm{kVAR}$ is required and a capacitor bank with a capacity of $300 \mathrm{kVAR}$ is installed.

3. The total active power after being subjected to togetherness in the planning of the new building of Aisyiyah University in Yogyakarta is 546.7 $\mathrm{kW}$ and the total apparent power after the power factor improvement is $594.2 \mathrm{kVA}$.

4. The maximum total normal load after the capacitor bank is installed is $594.2 \mathrm{kVA}$. Then the PLN power connection can be chosen, namely medium voltage capacity of $800 \mathrm{kVA}, 3$ phase, $50 \mathrm{~Hz}$.

5. The selected transformer capacity and generator capacity is $1000 \mathrm{kVA}$.

6. Lightning strikes against the new building of Aisyiyah University Yogyakarta are very large and securing lightning strikes against buildings is needed, therefore lightning rods chosen to protect buildings from lightning strikes are cage based Flash Vectron based on Early Streamer Emission (ESE).

\section{Acknowledgements}

This work was supported by Universitas Muhammadiyah Yogyakarta.

\section{References}

[1] Badan Standardisasi Nasional, Persyaratan Umum Instalasi Listrik 2000, vol. 2000, no. Puil. 2000.

[2] Badan Standardisasi Nasional, Tata Cara Perancangan Sistem Pencahayaan Buatan pada Bangunan Gedung. 2001.

[3] Hage, "Perbaikan Faktor Daya Menggunakan Kapasitor | Dunia Listrik,” 2008. [Online]. Available: http://dunia-listrik.blogspot.com/2008/12/perbaikanfaktor-daya-menggunakan.html. [Accessed: 08-May-
2018].

[4] International Electrotechnical Commission, "International Standard Short-circuit currents in three-phase a.c. systems," in 61010-1 (C) Iec:2001, vol. 07, 2001, p. 13.

[5] Badan Standardisasi Nasional, Tata Cara Perencanaan Proteksi Bangunan dan Peralatan terhadap Sambaran Petir. 2002.

[6] Badan Standardisasi Nasional, Sistem Proteksi Petir pada Bangunan Gedung. 2004.

\section{Authors' information}

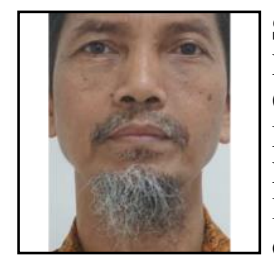

Slamet Suripto obtained his B. Eng in Electrical Engineering from Universitas Gadjah Mada, Indonesia in 1987. His Master study was done at the Electrical Engineering, Universitas Gadjah Mada, Indonesia. He currently is a lecture in department of electrical engineering, Universitas Muhammadiyah Yogyakarta.

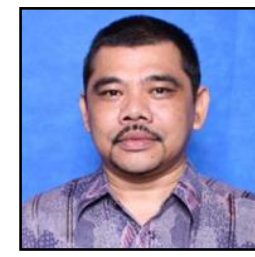

Agus Jamal obtained his B. Eng in Electrical Engineering from Universitas Gadjah Mada, Indonesia in 1994. His Master study was done at 2010 at the Electrical Engineering, Universitas Gadjah Mada, Indonesia. He currently is a lecture in department of electrical engineering, Universitas Muhammadiyah Yogyakarta.

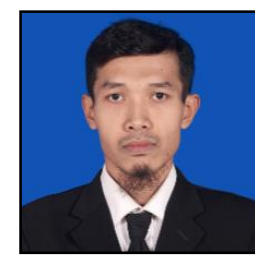

Kunnu Purwanto obtained his B. Eng in Electrical Engineering from Universitas Muhammadiyah Yogyakarta, Indonesia in 2009. His Master study was done at 2015 at the Electrical Engineering, Universitas Muhammadiyah Yogyakarta, Indonesia. He currently is a lecture in department of electrical engineering, Universitas Muhammadiyah Yogyakarta.

Wahyu Nugroho Wicaksono obtained his B. Eng in Electrical Engineering from Universitas Muhammadiyah Yogyakarta, Indonesia in 2018.

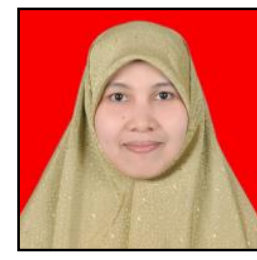

Yessi Jusman obtained her B. Eng in Electrical and Electronic Engineering from Andalas University, Indonesia in 2007. She worked as a Research Assistant started in July 2008 until November 2009 in Universiti Sains Malaysia. Her Master study was done at 2012 at the School of Electrical and Electronic Engineering, USM Engineering Campus in Nibong Tebal, Penang, Malaysia. She was finished her $\mathrm{PhD}$ degree at 2016 in University of Malaya with specializes in Image, Signal Processing, and algorithms. 